\title{
Immunoglobulin Switch Region
}

National Cancer Institute

\section{Source}

National Cancer Institute. Immunoglobulin Switch Region. NCI Thesaurus. Code C13244.

Nucleotide sequences found upstream of exons encoding the constant regions of

immunog lobulin heavy chains where exon rearrangement can occur. The combination of exons selected in a B-cell determines the immunoglobulin isotype produced by that cell. 